\title{
PHYTOREMEDIATION OF LANDFILL LEACHATE USING VETIVER (CHRYSOPOGON ZIZANIOIDES) AND CATTAIL (TYPHA LATIFOLIA)
}

\author{
RAMOS-ARCOS, S. A. ${ }^{1}$ - LÓPEZ-MARTÍNEZ, S. ${ }^{2 *}$ - LAGUNAS RiverA, S. ${ }^{3}$ - GONZÁLEZ- \\ MondRAGÓN, E. G. ${ }^{4}$ - DE LA CRUZ LEYVA, M. C. ${ }^{5}$ - VELÁZQUEZ-MARTÍNEZ, J. R. ${ }^{6}$ \\ ${ }^{1}$ División Académica de Ciencias Biológicas, Universidad Juárez Autónoma de Tabasco \\ Villahermosa, Tabasco, México \\ ${ }^{2}$ División Académica de Ciencias Biológicas, Universidad Juárez Autónoma de Tabasco \\ Carretera Villahermosa-Cárdenas Km. 0.5 S/N, Rancheria Emiliano Zapata, 86150 \\ Villahermosa, Tabasco, México \\ ${ }^{3}$ Catedrática CONACyt-Departamento de Química, DCNyE, Universidad de Guanajuato \\ Noria Alta s/n, 13 Guanajuato, Gto. 36050, México \\ (e-mail: slagunari@conacyt.mx) \\ ${ }^{4}$ Instituto de Agroindustrias, Universidad Tecnológica de la Mixteca \\ Huajuapan de León, Oaxaca, México \\ (e-mail: edith@mixteco.utm.mx) \\ ${ }^{5}$ División Académica Multidisciplinaria de los Ríos, Universidad Juárez Autónoma de Tabasco \\ Km. 1. Carretera Tenosique-Estapilla, 86901 Tenosique de Pino Suárez, Tabasco. México \\ (e-mail: concepcion.delacruz@ujat.com) \\ ${ }^{6}$ División Académica de Ciencias Agropecuarias, Universidad Juárez Autónoma de Tabasco. \\ Carretera Villahermosa-Teapa, $\mathrm{km} 25$, Ranchería La Huasteca $2^{a}$ \\ Sección, 86280. Villahermosa, Tabasco, México \\ (e-mail: jrodolfovelazquez@gmail.com) \\ *Corresponding author \\ e-mail: sugey.lopez@ujat.mx \\ (Received 14 ${ }^{\text {th }}$ Nov 2018; accepted $25^{\text {th }}$ Jan 2019)
}

\begin{abstract}
Several investigations have demonstrated the advantageous role that plants have in the phytoremediation of soils and waters contaminated by heavy metals. Therefore, under the present investigation, Chrysopogon zizanioides and Typha latifolia plants were tested for their effectiveness in absorbing 17 heavy metals (Al, B, Ba, Be, Co, Cr, Cu, Fe, Mg, Mn, Ni, Pb, S, Se, Tl, V and Zn) coming directly from a landfill leachate. The translocation factor was quantified in both species, where T. latifolia recorded a FT $>1 \%$ of the metals $\mathrm{V}, \mathrm{Ni}, \mathrm{Mn}$ and $\mathrm{B}$. While in C. zizanioides, the metals $\mathrm{Tl}, \mathrm{Se}, \mathrm{Co}$ and $\mathrm{B}$ obtained a FT $>1 \%$. In general, extraction was achieved without noticeable toxicity despite the excessive level of metals. These results demonstrate the suitability of these hyperaccumulator plants and establish them as a comfortable and inexpensive alternative to reduce water and soil pollution problems.
\end{abstract}

Keywords: leachate, plants, translocation factor, extraction, hyperaccumulator, pollution

\section{Introduction}

The continuous industrial and commercial growth in many countries around the world, in the last decade have been accompanied by a rapid increase in the production of both municipal and industrial solid waste (Renou et al., 2008), encouraging the search for 
alternative methods for the final disposal or confinement of waste (Białowiec, 2011), with the sanitary landfill being one such large-scale method, especially for municipal solid waste (Del Moro et al., 2014; Koda et al., 2016; Wong et al., 2015; Remmas et al., 2017) and urban solid waste (Renou et al., 2008).

Landfilling involves particular methods and engineering works that control leachate leakage (SEMARNAT, 2012). Leachate is defined as the aqueous effluent generated as a result of the filtration of rainwater through the wastes and the inherent water content of the wastes themselves deposited in landfills (Renou et al., 2008; Zapata and Zapata, 2013). They are generally high in contaminants (Roongtanakiat et al., 2003), especially heavy metals and organic and inorganic matter (Bulc, 2006) that can contaminate groundwater and surface water in the area near the landfill (Khattabi and Aleya, 2007; Öman and Junestedt, 2008).

The effects on human health and ecosystems associated with heavy metal pollution (Vaverková et al., 2018) become even more worrying given their tendency to accumulate and magnify along trophic levels (Anning and Akoto, 2018). For example, due to their bioaccumulation they can have toxic effects on living organisms when they exceed a certain concentration (Nriagu et al., 1991; Gusiatin et al., 2013; Mahmoud et al., 2014; Sas et al., 2015), representing a risk to human health when transferred thought the food chain (Kelly et al., 1996; Mazur et al., 2013; Radziemska et al., 2013; Mahmoud et al., 2014; Roy and McDonald, 2015).

Faced with this problem, phytoremediation is an energy-efficient, cost-effective and aesthetically pleasing alternative to remediation sites with low to moderate levels of pollution (Mojiri et al., 2015). It is a set of technologies that reduce in situ or ex situ the concentration of various compounds from biochemical processes carried out by plants and associated microorganisms (Kelley et al., 2001; Cherian and Oliveira, 2005; Eapen et al., 2007; Cho et al., 2008). Some of the plants widely used in phytoremediation are Chrysopogon zizanioides and Typha latifolia, both of which are widely distributed around the world.

Chrysopogon zizanioides, commonly known as vetiver, is a perennial herb of the Poaceae family, originally from India (Truong et al., 2009). It has a high tolerance to elevated concentrations of heavy metals such as $\mathrm{As}, \mathrm{Cd}, \mathrm{Cu}, \mathrm{Cr}, \mathrm{Pb}, \mathrm{Hg}, \mathrm{Ni}, \mathrm{Se}$ and $\mathrm{Zn}$, showing its unique physiological characteristics (Truong, 2002; Chomchalow, 2003; Shu, 2003; Danh et al., 2009; Truong et al., 2010; Vargas et al., 2016). C. zizanioides is considered efficient in purifying leachate from a landfill (Xia et al., 2000). In terms of its morphological characteristics, vetiver has a complex root system that can grow between 3 to $4 \mathrm{~m}$ per year, so the root can penetrate much deeper into the soil and water. This massive root system can reduce and prohibit deep drainage, improve soil stability and nutrient uptake (Danh et al., 2009; Truong, 2000).

Regarding Typha latifolia (common cattail) of the Typhaceae family, it is an aquatic, rooted, perennial herbaceous plant that grows extensively in tropical and warm regions, measuring 1.6 to $2.2 \mathrm{~m}$ high (Ye et al., 1997; Bonilla and Arauz, 2012). This species is expansive and widespread both in shallow lowland waters and in lower mountainous regions (Klink et al., 2013). It is characterized by high biomass production and a high rate of decomposition (Podbielkowski and Tomaszewicz, 1982). T. latifolia is used in phytoremediation because of its ability to remove heavy metals from impacted sites and accumulate them mainly in its roots (Hernández et al., 2014) which has suggested that root tissue cells can tolerate high concentrations of metals (Carranza-Álvarez et al., 2008; AlonsoCastro et al., 2009; Leura-Vicencio et al., 2013).

In the present study, the phytoremediation capacity of Chryzopogon zizanioides and Typha latifolia in leachate from a municipal landfill was evaluated, determining the concentration of 
heavy metals, Aluminum ( $\mathrm{Al})$, Boron $(\mathrm{B})$, Barium (Ba), Beryllium (Be), Cobalt $(\mathrm{Co})$, Chromium (Cr), Copper (Cu), Iron (Fe), Magnesium (Mg), Manganese (Mn), Nickel (Ni), Lead $(\mathrm{Pb})$, Selenium (Se), Thallium (Tl), Vanadium (V) and Zinc ( $\mathrm{Zn})$, by optical emission spectrometry with inductively coupled plasma (ICP-OES), and the translocation factor was calculated. The objective of the present study is to identify and measure the metals present in the heterogeneous mixture of the landfill leachate and to compare an introduced species that is C. zizanioides with T. latifolia native to Mexico. The originality of this work is centred on the type of contaminant in which the leachates are being used because most of the research focuses on a single metal or some metals in laboratory conditions without exploring how these metals would behave when they are in such a complex mixture as leachates without mentioning some other variants such as the type of soil being used. It is a pioneering work because the company opens the way for us to do research on these and other species found in the landfill.

\section{Materials and methods}

\section{Samples}

Collection of plants by simple random sampling of soil (contaminated and uncontaminated) as well as leachate was carried out at the sanitary landfill located in Leon, Guanajuato, Mexico (21 ${ }^{\circ} 10^{\prime} 30.12$ " N, 10146'29.25"). According to INEGI, $43 \%$ of the region's surface is represented by dry and semi-dry climate, mainly in the northern region; $33 \%$ of the surface, towards the southwest and east, is sub-humid warm climate and the remaining $24 \%$ has sub-humid temperate climate. The average annual temperature is $18{ }^{\circ} \mathrm{C}$. The rains are presented in summer, mainly in the months of June to September, the average precipitation of the state is approximately $650 \mathrm{~mm}$ annually. The collection of samples was during the month of October, in the dry period. The contaminated plants were taken from the landfill cells where they are irrigated with leachate that results from the decomposition of the deposited waste. The control plants were collected from the nursery located in the landfill facilities. At the collection points, 1 $\mathrm{kg}$ of rhizospheric soil and $300 \mathrm{~mL}$ of leachate from the leachate lagoon were also collected. They were stored at $4{ }^{\circ} \mathrm{C}$ until analysis.

\section{Analysis of samples}

The plants were washed and dried at room temperature. The shoots were separated from the roots, then cut and crushed in a mortar to obtain a particle size less than $2.0 \mathrm{~mm}$ (Farago et al., 1998). Subsequently, they were digested with $7 \mathrm{~mL}$ of $\mathrm{HNO}_{3}$ and $3 \mathrm{~mL}$ of tridestilled $\mathrm{H}_{2} \mathrm{O}$. On the other hand, soil samples were placed under shade to remove excess water, ground in a mortar and sieved using stainless steel meshes of $9.51 \mathrm{~mm}$ and $2 \mathrm{~mm}$ in diameter. They were digested in tridestilled $\mathrm{H}_{2} \mathrm{O}$ and $500 \mathrm{~mL} \mathrm{HNO}_{3}(1: 1, \mathrm{v} / \mathrm{v})$. Leachate was filtered using a $0.45 \mathrm{~m}$ filter (Farago et al., 1998) to remove particles that may interfere with the analyses. They were then digested with tridestilled $\mathrm{H}_{2} \mathrm{O}$ and $\mathrm{HNO}_{3}$, and a final volume of $25 \mathrm{~mL}$ with tridestilled $\mathrm{H}_{2} \mathrm{O}$ was measured.

All previously digested samples were analyzed by means of an optical emission spectrometer with inductively coupled plasma (IRIS Advantage, Thermo Jarrell Ash Co.), with the software. A multi-element calibration curve was used including 16 chemical elements: $\mathrm{Al}, \mathrm{B}, \mathrm{Ba}, \mathrm{Be}, \mathrm{Co}, \mathrm{Cr}, \mathrm{Cu}, \mathrm{Fe}, \mathrm{Mg}, \mathrm{Mn}, \mathrm{Ni}, \mathrm{Pb}, \mathrm{Se}, \mathrm{Tl}, \mathrm{V}, \mathrm{Zn}$, prepared from a commercial standard Sigma Aldrich solution. 
Three repetitions per sample were made for the analysis of metals in plants, soils and leachate.

\section{Translocation factor}

The translocation factor (TF) is an indication whether or not a plant can be considered as a hyperaccumulator of chemical elements, it was determined based on the concentrations of metals in plants, soils and leachate, as well as their respective controls, according to the following formula (Mendieta and Taisigue, 2014) as shown in Equation 1:

$$
\text { Translocation factor }=\frac{\text { Concentration of metals in shoots }}{\text { Concentration of metals in roots }}
$$

\section{Statiscal analysis}

An analysis of variance (ANOVA) was made using the statistical program SPSS 12 for Windows, used to discriminate between the means the procedure of Honestly Significant Difference (HSD) of Tukey, with a level of significance $\alpha=0.05$.

\section{Results}

\section{Concentration of heavy metals in the leachate}

The concentrations of heavy metals in the leachate are presented in (Table 1) (average of the replicas performed) where the results are compared with those from a study carried out by Öman and Junestedt (2008) on leachate from Swedish municipal landfills.

Table 1. Heavy metal concentrations $(\mu g / L)$ of leachate of the site studied and the corresponding threshold limit values

\begin{tabular}{c|c|c}
\hline Metal & Concentration & Threshold Limit \\
\hline $\mathrm{Al}$ & $1.09( \pm 0.0)$ & 209 \\
$\mathrm{~B}$ & $133.3( \pm 86.0)$ & 2580 \\
$\mathrm{Ba}$ & $810.8( \pm 343.5)$ & 280 \\
$\mathrm{Be}$ & $12.5( \pm 22.9)$ & 0.065 \\
$\mathrm{Co}$ & $12.5( \pm 6.9)$ & 7.7 \\
$\mathrm{Cr}$ & $27.34( \pm 64.5)$ & 15.3 \\
$\mathrm{Cu}$ & $4.52( \pm 28.2)$ & 23 \\
$\mathrm{Fe}$ & $249.9( \pm 2.3)$ & 6500 \\
$\mathrm{Mg}$ & $202.5( \pm 13.4)$ & 47,900 \\
$\mathrm{Mn}$ & $145.3( \pm 13.6)$ & 1152 \\
$\mathrm{Ni}$ & $36.01( \pm 5.6)$ & 31 \\
$\mathrm{~Pb}$ & $8.5( \pm 2.3)$ & 4.4 \\
$\mathrm{~S}$ & $825.9( \pm 87.6)$ & 90,800 \\
$\mathrm{Se}$ & $25.12( \pm 0.1)$ & 27 \\
$\mathrm{Tl}$ & $223.9( \pm 35.7)$ & 0.12 \\
$\mathrm{~V}$ & $210.9( \pm 38.4)$ & 16 \\
$\mathrm{Zn}$ & $202.5( \pm 13.4)$ & 66 \\
\hline
\end{tabular}

Values in parentheses are standard deviation 


\section{Capture of heavy metals in T. latifolia and C. zizanioides}

The concentration of the heavy metals found in Typha latifolia and Chrysopogon zizanioides, as well as their respective controls, are shown in (Table 2).

Table 2. Concentration of heavy metals in vetiver and cattail expressed in $\mathrm{mg} / \mathrm{kg}$

\begin{tabular}{c|c|c|c|c}
\hline \multirow{2}{*}{ Metal } & \multicolumn{2}{|c|}{ Cattail } & \multicolumn{2}{|c}{ Vetiver } \\
\cline { 2 - 5 } & Contaminated & Control & Contaminated & Control \\
\hline $\mathrm{Al}$ & $4.92( \pm 0.5)$ & $1.08( \pm 0.3)$ & $3.70( \pm 0.4)$ & $0.71( \pm 0.0)$ \\
$\mathrm{B}$ & $7.23( \pm 1.1)$ & $0.51( \pm 0.0)$ & $4.23( \pm 0.0)$ & $0.39( \pm 0.0)$ \\
$\mathrm{Ba}$ & $205.24( \pm 15.4)$ & $6.72( \pm 0.1)$ & $76.00( \pm 2.6)$ & $4.89( \pm 0.4)$ \\
$\mathrm{Be}$ & $4.13( \pm 0.6)$ & $0.29( \pm 0.1)$ & $2.97( \pm 0.2)$ & $0.26( \pm 0.0)$ \\
$\mathrm{Co}$ & $0.25( \pm 0.0)$ & $0.00( \pm 0.0)$ & $0.37( \pm 0.1)$ & $0.00( \pm 0.0)$ \\
$\mathrm{Cr}$ & $1.07( \pm 0.0)$ & $0.00( \pm 0.0)$ & $0.55( \pm 0.0)$ & $0.00( \pm 0.0)$ \\
$\mathrm{Cu}$ & $1.57( \pm 0.2)$ & $0.00( \pm 0.0)$ & $1.15( \pm 0.1)$ & $0.00( \pm 0.0)$ \\
$\mathrm{Fe}$ & $95.18( \pm 31.7)$ & $2.64( \pm 0.1)$ & $105.67( \pm 14.8)$ & $2.10( \pm 0.2)$ \\
$\mathrm{Mg}$ & $75.98( \pm 8.3)$ & $4.92( \pm 0.5)$ & $10.54( \pm 1.4)$ & $3.10( \pm 0.1)$ \\
$\mathrm{Mn}$ & $264.70( \pm 4.3)$ & $2.47( \pm 0.3)$ & $46.82( \pm 0.5)$ & $1.92( \pm 0.1)$ \\
$\mathrm{Ni}$ & $2.32( \pm 0.1)$ & $0.20( \pm 0.1)$ & $2.65( \pm 0.0)$ & $0.06( \pm 0.0)$ \\
$\mathrm{Pb}$ & $0.96( \pm 0.0)$ & $0.30( \pm 0.2)$ & $1.41( \pm 0.0)$ & $0.07( \pm 0.0)$ \\
$\mathrm{S}$ & $111.76( \pm 9.6)$ & $0.00( \pm 0.0)$ & $54.93( \pm 4.1)$ & $0.04( \pm 0.0)$ \\
$\mathrm{Se}$ & $0.79( \pm 0.2)$ & $0.15( \pm 0.2)$ & $0.80( \pm 0.0)$ & $0.17( \pm 0.0)$ \\
$\mathrm{Tl}$ & $16.14( \pm 0.2)$ & $0.05( \pm 0.1)$ & $17.23( \pm 0.2)$ & $0.00( \pm 0.0)$ \\
$\mathrm{V}$ & $18.54( \pm 1.5)$ & $1.57( \pm 0.1)$ & $18.79( \pm 0.0)$ & $1.07( \pm 0.0)$ \\
$\mathrm{Zn}$ & $15.40( \pm 3.3)$ & $1.12( \pm 0.4)$ & $6.54( \pm 1.0)$ & $0.58( \pm 0.1)$ \\
\hline $\mathrm{V}$ & & &
\end{tabular}

Values in parentheses are standard deviation

\section{Concentration of metals in biomass of species}

A statistically significant difference $(\mathrm{p}<0.05)$ was recorded in the absorbed concentration of each metal between the plants, as well as in their evaluated parts (shoots and roots). The concentration of metals was observed in the roots and in the shoots as shown in Figures 1 and 2.
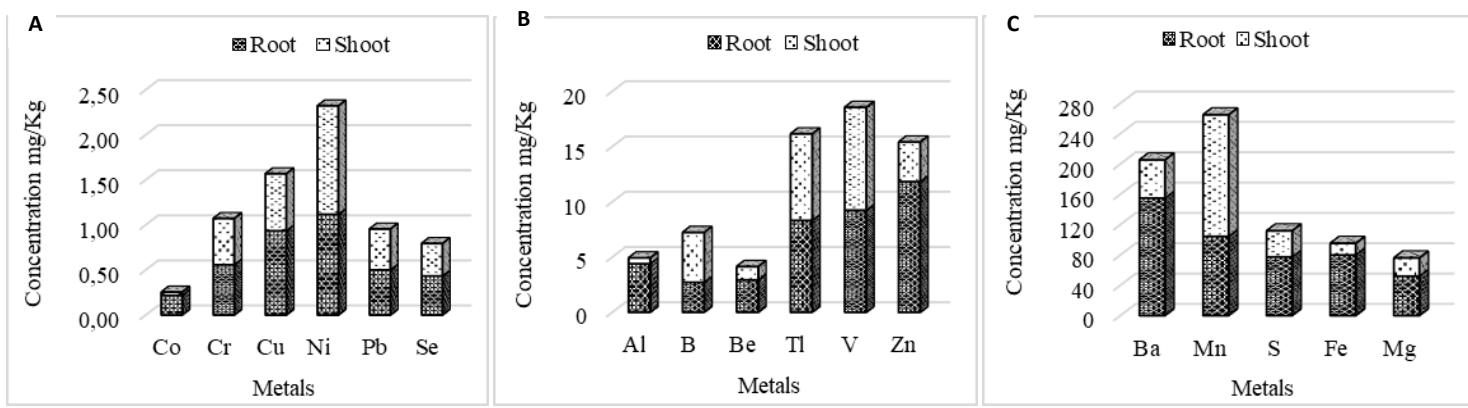

Figure 1. Concentration of metals in cattail biomass 

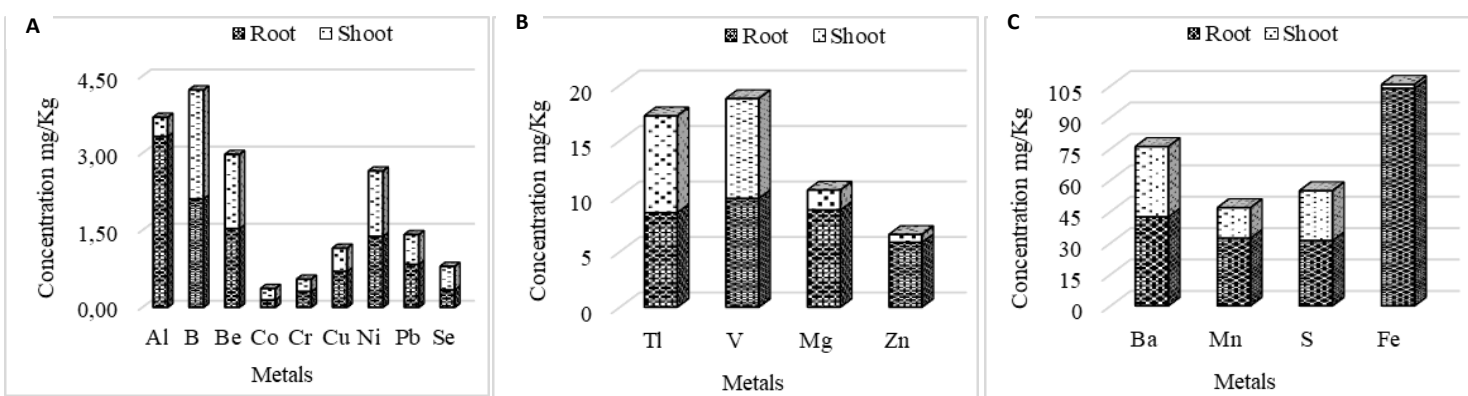

Figure 2. Concentration of metals in vetiver biomass

\section{Translocation factor}

Successful phytoremediation evaluates results by emphasizing the ability to accumulate and transfer metals. While plant species may naturally accumulate heavy metals in their roots, a chemical amendment may be necessary to achieve effective translocation of such metals in plant shoots (Anning and Akoto, 2018). Baker (1981) points out that an FT above $1 \%$ indicates that a translocation from the root to the aerial part of the plant occurs. Plants with FT $>1$ are considered accumulators or hyperaccumulators (if concentrations exceed 0.1\%) (Mendieta and Taisigue, 2014), indicating that they are capable of accumulating excessive amounts of heavy metals.

Translocation factor (FT) values for all metals in cattail and vetiver are shown in Figures 3 and 4.

\section{Discussion}

\section{Concentration of heavy metals in the leachate}

Concentrations of heavy metals in the leachate exceeded the limits of the standard threshold Table 1. The threshold limits for metals come from a study conducted by Öman and Junestedt (2008) on leachate from Swedish municipal landfills. Heavy metal concentrations $(\mu \mathrm{g} / \mathrm{L})$ of leachate from the site studied and corresponding threshold limit values.

Seventeen heavy metals were identified: S, Ba, Fe, Tl, V, Mg, Zn, Mn, B, Ni, Cr, Se, $\mathrm{Be}, \mathrm{Co}, \mathrm{Pb}, \mathrm{Cu}$ and $\mathrm{Al}$, in descending order of concentration $(\mu \mathrm{g} / \mathrm{L})$. As can be seen, $\mathrm{S}$ is the metal with the highest absorption, with a concentration of $825.9 \mu \mathrm{g} / \mathrm{L}$. But it failed to exceed the threshold concentration with a value of $90.800 \mu \mathrm{g} / \mathrm{L}$. Aluminium was the least abundant metal with a concentration of $1.09 \mu \mathrm{g} / \mathrm{L}$ and differed with the reference site $(209 \mu \mathrm{g} / \mathrm{L})$. On the other hand, some metals (Ba, Be, Co, Cr, Ni, Pb, Tl, V and $\mathrm{Zn}$ ) obtained a higher concentration than the threshold level. Ba obtained a concentration of $810.8 \mu \mathrm{g} / \mathrm{L}$ while the threshold level concentration was $280 \mu \mathrm{g} / \mathrm{L}$. The concentration of $\mathrm{Be}(12.5 \mu \mathrm{g} / \mathrm{L})$ and $\mathrm{Co}(12.5 \mu \mathrm{g} / \mathrm{L})$ were higher than the threshold concentrations $(0.065$ and $7.7 \mu \mathrm{g} / \mathrm{L}$ respectively). In contrast, $\mathrm{Tl}, \mathrm{V}$ and $\mathrm{Zn}$ showed relatively high concentrations $(223.9,210.9$ and $202.5 \mu \mathrm{g} / \mathrm{L}$ respectively) compared to the corresponding threshold levels of $0.12,16$ and $66 \mu \mathrm{g} / \mathrm{L}$. Ni reached a concentration of $36.01 \mu \mathrm{g} / \mathrm{L}$, just above the threshold level $(31 \mu \mathrm{g} / \mathrm{L})$. The threshold concentrations of $\mathrm{Cr}$ and $\mathrm{Pb}$ were $15.3,31$ and $4.4 \mu \mathrm{g} / \mathrm{L}$ respectively, while the concentrations obtained in the study area were 27.34 and $8.5 \mu \mathrm{g} / \mathrm{L}$ respectively. 

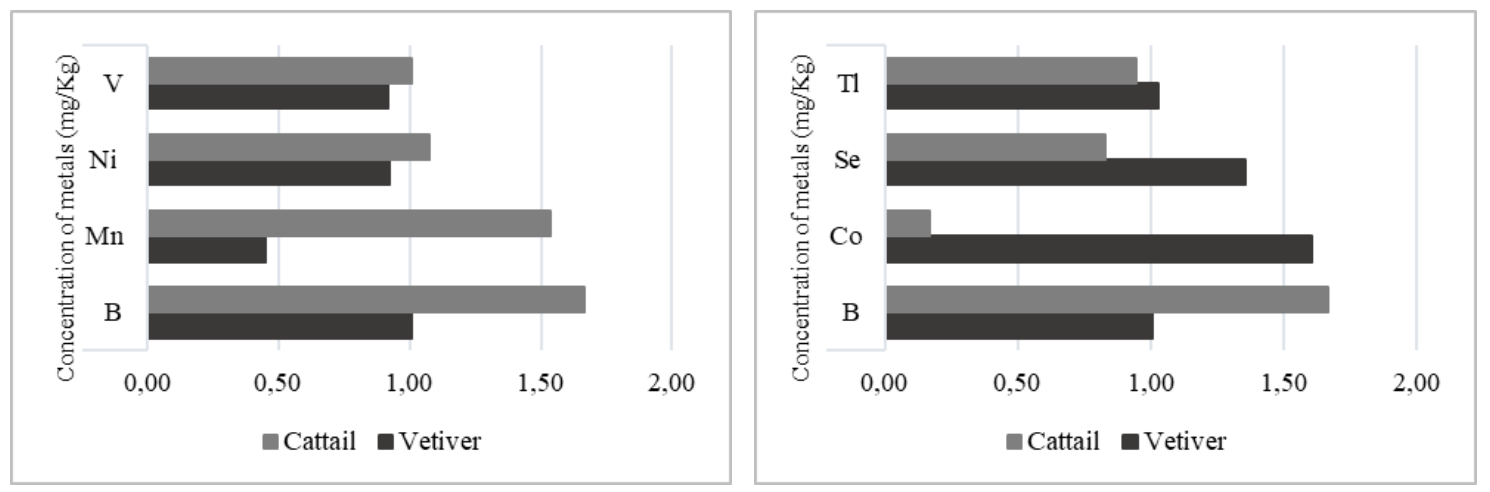

Figure 3. Translocation factor $>1 \%$ of heavy metals in cattail and vetiver

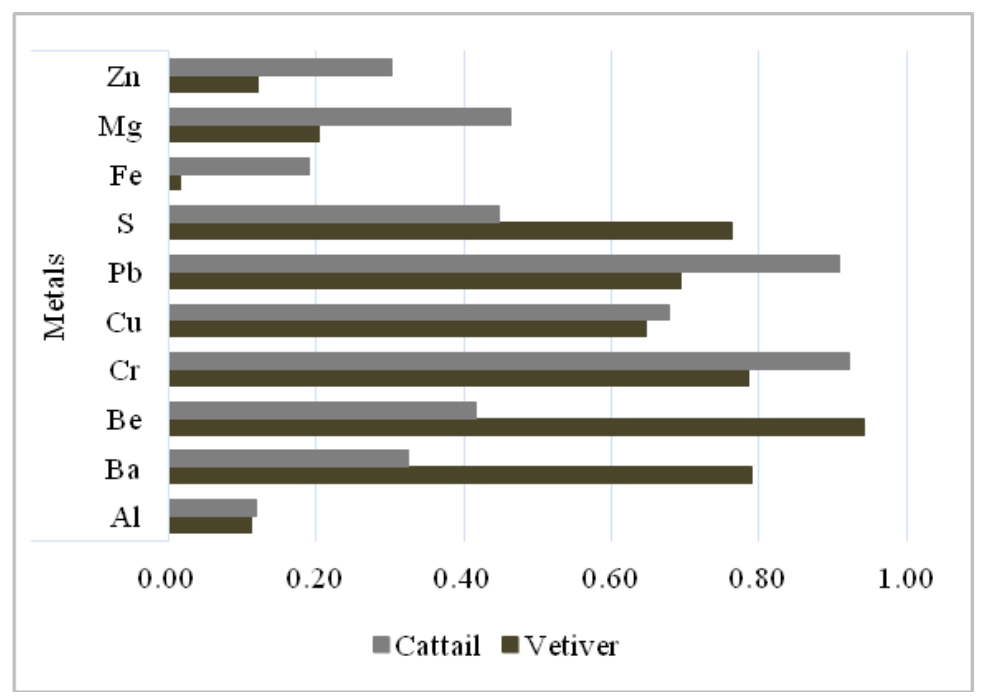

Figure 4. Translocation factor $<1 \%$ in heavy metals in cattail and vetiver

According to Méndez et al. (2004), the composition of a leachate from a sanitary landfill depends on factors such as: the initial degree of humidity of the residues, rainfall, atmospheric humidity, temperature and evaporation. It generally has a high content of pollutants, especially heavy metals and other harmful substances that become pollution in the area around landfills and in groundwater if they infiltrate (Roongtanakiat et al., 2003). As already mentioned, heavy metals are very harmful to the environment and human health due to their toxicity, persistence and nondegradability. These effects can be particularly problematic, requiring environmentally friendly and cost-effective remediation measures, such as phytoremediation (Ghosh and Singh, 2005; Ali et al., 2013).

\section{Uptake of heavy metals in T. latifolia and C. zizanioides}

In both plant species the 17 heavy metals also present in the previously analyzed leachate were identified. In the contaminated samples almost null concentrations $(<1 \mathrm{mg} / \mathrm{kg})$ up to high concentrations $(>200 \mathrm{mg} / \mathrm{kg})$ were detected. However, in both controls no values were recorded for $\mathrm{Co}, \mathrm{Cr}$ and $\mathrm{Cu}$, nor for $\mathrm{S}$ and $\mathrm{Tl}$ in cattail and vetiver, respectively. The highest uptake was in the cattail plant was for heavy metals: 
$\mathrm{Mn}, \mathrm{Ba}, \mathrm{S}, \mathrm{Mg}, \mathrm{Zn}, \mathrm{B}, \mathrm{Al}, \mathrm{Be}, \mathrm{Cu}$ and $\mathrm{Cr}$, in descending order of concentration, and in vetiver were $\mathrm{Fe}, \mathrm{Tl}, \mathrm{Ni}, \mathrm{Pb}$ and $\mathrm{Co}$. For $\mathrm{Se}$ and $\mathrm{V}$ showed very similar concentration values in both contaminated plants analyzed.

Considering the relationship between the concentration present in the contaminated plant and its control, it was observed that vetiver had the highest uptake of $\mathrm{Al}, \mathrm{Fe}, \mathrm{Ni}$, $\mathrm{Pb}$ and $\mathrm{V}$; and for cattail the ones with the highest uptake were $\mathrm{B}, \mathrm{Ba}, \mathrm{Be}, \mathrm{Mg}, \mathrm{Mn}, \mathrm{Se}$, $\mathrm{Tl}$ and $\mathrm{Zn}$. The analysis of variance showed a statistically significant difference $(p<0.05)$ between the concentration of each metal present in the contaminated plant and its respective control.

It is necessary to mention that some are essential elements, and are essential for the maintenance of the biochemical systems of all individuals (Yaman and Akdeniz, 2004). Several elements are essential for the growth, reproduction and/or survival of living organisms; others are of great economic and industrial importance and, from a toxicological point of view, their importance is enormous, presenting a multiplicity of toxic effects.

Based on the results, the cattail can be considered as an accumulator plant, reaching a higher uptake of heavy metals with respect to its control and vetiver. It has been reported the effectiveness of the cattail to capture $\mathrm{Al}, \mathrm{Cu}$ and $\mathrm{Zn}$ (Margalef, 198 and Syukor et al., 2016,), as well as Mg, Cr and Mn (Sarkar et al., 2017), but not the uptake of $\mathrm{Ba}, \mathrm{S}, \mathrm{Fe}, \mathrm{V}, \mathrm{Tl}, \mathrm{B}, \mathrm{Be}, \mathrm{Ni}, \mathrm{Pb}, \mathrm{Se}$ and $\mathrm{Co}$.

With respect to vetiver, it seems to be a more effective accumulator of $\mathrm{S}, \mathrm{Fe}, \mathrm{Ni}, \mathrm{Pb}$, $\mathrm{V}, \mathrm{Al}, \mathrm{Tl}, \mathrm{Cu}, \mathrm{Co}$ and $\mathrm{Cr}$. Truong (2000) reported for vetiver the uptake of $\mathrm{Co}, \mathrm{Ni}$ and Se (50-100, 100, >74 mg/kg, respectively), in concentrations higher than those obtained in the present work $(0.37,2.65$ and $0.8 \mathrm{mg} / \mathrm{kg}$, respectively). The concentrations of Fe and $\mathrm{Pb}$ were higher (105.67 and $1.41 \mathrm{mg} / \mathrm{kg}$, respectively) than those reported by Suelee et al. (2017) $(0.08$ and $0.31 \mathrm{mg} / \mathrm{kg}$, respectively). It should be noted that the metals $\mathrm{V}$ and $\mathrm{Tl}$ have not been reported in investigations carried out in vetiver as a phytoremediation plant, being two of the elements with higher concentration (18.79 and $17.23 \mathrm{mg} / \mathrm{kg}$, respectively) with respect to all those identified in this plant.

\section{Concentration of metals in biomass of species}

The highest concentration of metals was observed in the roots as shown in Figures 1 and 2. The metals with the highest concentration in the roots of both species evaluated were: $\mathrm{Al}, \mathrm{Ba}, \mathrm{Be}, \mathrm{Cr}, \mathrm{Cu}, \mathrm{Pb}, \mathrm{S}, \mathrm{V}, \mathrm{Fe}, \mathrm{Mg}$ and $\mathrm{Zn}$, with those of cattail showing the highest uptake of metals ( $\mathrm{Al}, \mathrm{Ba}, \mathrm{Be}, \mathrm{Cu}, \mathrm{Mg}, \mathrm{S}$ and $\mathrm{Zn}$ ), compared to the roots of Vetiver ( $\mathrm{Fe}, \mathrm{Ni}, \mathrm{Pb}$ and $\mathrm{V}$ ). In the leaves the elements with the highest concentration were $\mathrm{B}, \mathrm{Co}, \mathrm{Mn}, \mathrm{Ni}, \mathrm{Se}$ and $\mathrm{Tl}$. The belfry $\mathrm{B}, \mathrm{Mn}$ and $\mathrm{Ni}$, obtained higher concentrations in the leaves $(4.51,160.42$ and $1.20 \mathrm{mg} / \mathrm{kg})$. Vetiver leaves had higher concentrations of $\mathrm{Co}$, Se and $\mathrm{Tl}(0.23,0.46,8.73 \mathrm{mg} / \mathrm{kg}$, respectively).

\section{Translocation factor (FT)}

Successful phytoremediation evaluates results by emphasizing the ability to accumulate and transfer metals. While plant species may naturally accumulate heavy metals in their roots, a chemical amendment may be necessary to achieve effective translocation of such metals in plant shoots (Anning and Akoto, 2018). Baker (1981) points out that an TF above $1 \%$ indicates that a translocation from the root to the aerial part of the plant occurs. Plants with $\mathrm{TF}>1$ are considered accumulators or 
hyperaccumulators (if concentrations exceed 0.1\%) (Mendieta and Taisigue, 2014), indicating that they are capable of accumulating excessive amounts of heavy metals. The translocation factor (TF) values for all metals in cattail and vetiver are shown in Figures 3 and 4.

In general, the translocation values of metals in plants presented a statistically significant difference $(\mathrm{p}<0.05)$ between plants. The cattail recorded a TF $>1 \%$ for $\mathrm{V}$ (1.01\%), Ni (1.08\%), Mn (1.54\%) and B (1.66\%), being higher for the latter. In the case of vetiver the metals that obtained a TF >1\% were: B (1.01\%), Tl (1.03\%), Se (1.36\%) and Co $(1.60 \%)$. As can be seen in Figure 3, B presented 1.66 in the cattail and 1.01 in the vetiver.

The rest of the metals presented a FT $<1 \%$, for both evaluated plant species. According to Mendieta and Taisigue (2014), TF values between 0.1 and $1 \%$ indicate that plants are considered tolerant of these metals.

From the current results, the cattail seems to be a more effective accumulator and, to some extent, a translocator of $\mathrm{V}, \mathrm{Ni}, \mathrm{Mn}$ and $\mathrm{B}$ than the vetiver, which apparently has a greater affinity for Tl, Se, Co and B.

Research has established that both plants are able to absorb heavy metals from landfill leachate (in situ). Being the cattail, the species that achieved a higher concentration of heavy metals, specifically in their roots. As for vetiver, it successfully captured the metals, however, its concentrations are $10 \%$ lower than those of the cattail.

\section{Conclusions}

This study showed that the composition of the leachate analyzed from a sanitary landfill in Mexico, which due to its heavy metal content poses a risk to human health and the environment, therefore successful mitigation measures are required. The two plants, T. latifolia and $C$. zizanioides, studied in the phytoremediation of different heavy metals present in the previously characterized leachate, proved to be highly effective in capturing seventeen heavy metals present in the previously characterized sanitary landfill, which was supported by the TF values that were used as an indication of the suitability of these plants for phytoremediation. The use of these species indicates that it could be cosmopolitan due to its attributes of remediation of diverse pollutants being economic resources and of easy access. The results obtained will allow progress in the management of degraded spaces and their restoration through innovative phytoremediation techniques.

Recommendations based on the results, considerations should be taken, such as applying the process of phytoextraction assisted by chelating agents in situ, to evaluate and quantify the effect that these chelating agents have on the availability of metals in plant species. As well as to study the autochthonous microorganisms of the rhizospheric soil that participate during the removal of metals. On the other hand, to evaluate the relation plant-soil-microorganisms and to characterize the exudates that are produced in a natural way, for these conditions to define if these compete with organic acids of reactive grade.

Acknowledgements. This study was financed by Promotora Ambiental S.A.B. de C.V. Directed by Dr. Sugey López Martínez. I am also grateful for the scholarship granted by the National Council for Science and Technology (CONACyT) with scholarship No. 430983 during my postgraduate studies in Master's in Environmental Sciences (PNPC). 


\section{REFERENCES}

[1] Ali, H., Khan, E., Sajad, A. M. (2013): Phytoremediation of heavy metals-concepts and applications. - Chemosphere 91: 869-881.

[2] Alonso-Castro, A. J., Carranza-Álvarez, C., Alfaro-de la Torre, M. C., Chávez-Guerrero, L., García-De la Cruz, R. F. (2009): Removal and accumulation of cadmium and lead by Typha latifolia exposed to single and mixed metal solutions. - Arch Environ Contam Toxicol 57: 688-696.

[3] Anning, A. K., Akoto, R. (2018): Assisted phytoremediation of heavy metal contaminated soil from a mined site with Typha latifolia and Chrysopogon zizanioides. Ecotoxicology and Environmental Safety 148: 97-104.

[4] Baker, A. J. M. (1981): Accumulators and excludersstrategies in the response of plants to heavy metals. - Journal Plant Nutrition 3: 643-654.

[5] Białowiec, A. (2011): Hazardous emissions from municipal solid waste landfills. Some aspects of environmental impact of waste dumps. - Contemporary Problems of Management and Environmental Protection 9: 1-18.

[6] Bonilla-Barbosa, J. R., Araúz, B. S. (2012): Flora del Bajío y de regiones adyacentes. Instituto de Ecologia, Mexico.

[7] Bulc, T. G. (2006): Long-term performance of constructed wetlands for landfill leachate treatment. - Ecol. Eng. 26: 365-374.

[8] Carranza-Álvarez, C., Alonso-Castro, A. J., Alfaro-De La Torre, M. C., García-De La Cruz, R. F. (2008): Accumulation and distribution of heavy metals in Scirpus americanus and Typha latifolia from an artificial lagoon in San Luis Potosí, México. - Water Air Soil Pollut 188: 297-309.

[9] Cherian, S., Oliveira, M. (2005): Transgenic plants in phytoremediation: recent advances and new possibilities. - Environmental Science \& Technology. 39: 9377-9390.

[10] Cho, C., Yavuz-Corapcioglu, M., Park, S., Sung, K. (2008): Effects of grasses on the fate of VOCs in contaminated soil and air. - Water, Air, \& Soil Pollution. 187: 243-250.

[11] Chomchalow, N. (2003): The role of Vetiver in controlling water quantity and treating water quality: an overview with special reference to Thailand. - AU J T 6(3): 145-116.

[12] Danh, L. T., Truong, P., Mammucari, R., Tran, T., Foster, N. (2009): Vetiver grass, Vetiveria zizanioides: a choice plant for phytoremediation of heavy metals and organic wastes. - International Journal of Phytoremediation 11: 664-691.

[13] Del Moro, G., Barca, E., Cassano, D., Di Iaconi, C., Mascolo, G., Brunetti, G. (2014): Landfill wall revegetation combined with leachate recirculation: a convenient procedure for management of closed landfills. - Environmental Science and Pollution Research 21(15): 9366-9375.

[14] Eapen, S., Singh, S., D'Souza, S. F. (2007): Advances in development of transgenic plants for remediation of xenobiotic pollutants. - Biotechnology Advances. 25: 442-451.

[15] Farago, M. E., Kavanagh, P., Blanks, R., Kelly, J., Kazantzis, G., Thornton, I., Hall, G. E. (1998): Platinum concentrations in urban road dust and soil, and in blood and urine in the United Kingdom. - Analyst 123(3): 451-454.

[16] Ghosh, M., Singh, S. P. (2005): A review on phytoremediation of heavy metals and utilization of its by-products. - Appl. Ecol. Environ. Res. 3(1): 1-18.

[17] Gusiatin, Z. M. (2013): Use of sewage sludge-compost in remediation of soil contaminated with $\mathrm{Cu}, \mathrm{Cd}$ and $\mathrm{Zn}$. - Environ. Eng. 4: 213-223.

[18] Hernández, A., Rubio, J., Carranza, C., Álvarez, C., Aguilar, J. R. P. (2014): Obtención de aislados bacterianos de la rizósfera de Typha latifolia (Espadaña) crecida en sitios contaminados con Plomo. - Ciencias Naturales y Exactas Handbook T-II: Congreso Interdisciplinario de Cuerpos Académicos, ECORFAN, pp. 200-208.
[19] INEGI
(n.
d.):
Conociendo
Guanajuato.

http://internet.contenidos.inegi.org.mx/contenidos/productos/prod_serv/contenidos/espan $\mathrm{ol} /$ bvinegi/productos/estudios/conociendo/Guanajuato.pdf. 
[20] Kelley, S., Aitchison, E., Deshpande, M., Schnoor, J., Alvarez, P. (2001): Biodegradation of 1:4-dioxane in planted and unplanted soil: effect of bioaugmentation with Amycolata sp. CB1190. - Water Res. 35: 3791-3800.

[21] Kelly, J., Thornton, I., Simpson, P. R. (1996): Urban geochemistry: a study of influence of anthropogenic activity on heavy metal content of soils in traditionally industrial and non-industrial areas of Britain. - Appl. Geochem. 11: 363-370.

[22] Khattabi, H., Aleya, L. (2007): The dynamics of macroinvertebrate assemblages in response to environmental change in four basins of the Etueffont landfill leachate (Belfort, France). - Water, Air, Soil Pollut. 185: 63-77.

[23] Klink, A., Macioł, A., Wisłocka, M., Krawczyk, J. (2013): Metal accumulation and distribution in the organs of Typha latifolia L. (cattail) and their potential use in bioindication. - Limnologica-Ecology and Management of Inland Waters 43(3): 164-168.

[24] Koda, E., Sieczka, A., Osiński, P. (2016): Ammonium concentration and migration in groundwater in the vicinity of waste management site located in the neighborhood of protected areas of Warsaw, Poland. - Sustainability 8: 1253.

[25] Leura-Vicencio, A., Alonso-Castro, A. J., Carranza-Álvarez, C., Loredo-Portales, R., Alfaro de la Torre, M. C. (2013): Removal and accumulation of As, Cd and Cr by Typha latifolia. - Bull Environ Contam Toxicol 90(6): 650-653.

[26] Mahmoud, E., El-Kader, N. A. (2014): Heavy metal immobilization in contaminated soils using phosphogypsum and rice straw compost. - Land Degrad. Dev. 26: 819-824.

[27] Margalef, R. (1981): Distribución de los macrófitos de las aguas dulces y salobres del E y NE de España y dependencia de la composición química del medio. - Fundación Juan March.

[28] Mazur, Z., Radziemska, M., Maczuga, O., Makuch, A. (2013): Heavy metal concentrations in soil and moss (Pleurozium schreberi) near railroad lines in Olsztyn (Poland). - Fres. Environ. Bull. 22: 955-961.

[29] Méndez, R., Castillo, E., Sauri, M., Quintal, C., Giancoman, G., Jiménez, B. (2004): Tratamiento fisicoquímico de los lixiviados de un relleno sanitario. - Ingeniería 8(2).

[30] Mendieta, B., Taisigue, K. (2014): Acumulación y traslocación de metales, metaloides y no metales en plantas nativas de la zona minera de Chontales: Implicaciones para el potencial de fitorremediación. - Laboratorio de Biotecnología, UNAM, Managua, pp. 112.

[31] Mojiri, A., Aziz, H. A., Tajuddin, R. B. M., Gavanji, S., Gholami, A. (2015): Heavy Metals Phytoremediation from Urban Waste Leachate by the Common Reed (Phragmites australis). - In: Ansari, A. A. et al. (eds.) Phytoremediation. Springer, Cham, pp. 75-81.

[32] Nriagu, J. O. (1990): Human influence on the global cycling of trace metals. Palaeogeography, Palaeoclimatology, Palaeoecology 82(1-2): 113-120.

[33] Öman, C. B., Junestedt, C. (2008): Chemical characterization of landfill leachates -400 parameters and compounds. - Waste Management 28(10): 1876-1891.

[34] Podbielkowski, Z., Tomaszewicz, H. (1982): Zarys hydrobotaniki (Overview of Hydrobotany). - PWN, Warszawa.

[35] Radziemska, M., Mazur, Z., Jeznach, J. (2013): Influence of applying halloysite and zeolite to soil contaminated with nickel on the content of selected elements in Maize (Zea mays L.). - Chem. Eng. Trans. 32: 301-306.

[36] Remmas, N., Roukouni, C., Ntougias, S. (2017): Bacterial community structure and prevalence of Pusillimonas-like bacteria in aged landfill leachate. - Environ. Sci. Pollut. Res. 24(7): 6757-6769.

[37] Renou, S., Givaudan, J. G., Poulain, S., Dirassouyan, F., Moulin, P. (2008): Landfill leachate treatment: review and opportunity. - Journal of Hazardous Materials 150(3): 468-493.

[38] Roongtanakiat, N., Nirunrach, T., Chanyotha, S., Hengchaovanich, D. (2003): Uptake of heavy metals in landfill leachate by Vetiver grass. - Kasetsart J.(Nat. Sci.): 37(2): 168175 . 
[39] Roy, M., McDonald, L. M. (2015): Metal uptake in plants and health risk assessments in metal-contaminated smelter soils. - Land Degrad. Dev. 26: 785-792.

[40] Sarkar, S. R., Majumdar, A., Barla, A., Pradhan, N., Singh, S., Ojha, N., Bose, S. (2017): A conjugative study of Typha latifolia for expunge of phyto-available heavy metals in fly ash ameliorated soil. - Geoderma 305: 354-362.

[41] Sas, W., Głuchowski, A., Radziemska, M., Dzięcioł, J., Szymański, A. (2015): Environmental and geotechnical assessment of the steel slags as a material for road structure. - Materials 8: 4857-4875.

[42] SEMARNAT (2012): Subsecretaría de gestión para la protección ambiental. - México.

[43] Shu, W. S. (2003): Exploring the potential utilization of vetiver in treating acid mine drainage (AMD). - Third international Vetiver conference 2003. University of Guangzhou, China. Oct 6.

[44] Suelee, A. L., Hasan, S. N. M. S., Kusin, F. M., Yusuff, F. M., Ibrahim, Z. Z. (2017): Phytoremediation potential of vetiver grass (Vetiveria zizanioides) for treatment of metalcontaminated water. - Water, Air, \& Soil Pollution 228(4): 158.

[45] Sulaiman, S., Siddique, M. N. I., Zularisam, A. W., Said, M. I. M. (2016): Integration of phytogreen for heavy metal removal from wastewater. - Journal of Cleaner Production 112: 3124-3131.

[46] Truong, P. (2000): The global impact of vetiver grass technology on the environment. Proceedings of the Second International Conference on Vetiver. Office of the Royal Development Projects Board, Bangkok, pp. 48-61.

[47] Truong, P. (2002): Vetiver Grass Technology. - In: Maffei, M. (ed.) Vetiveria: The Genus Veteveria. Taylor \& Francis, New York, pp. 114-132.

[48] Truong, P., Van, T. T., Pinners. E. (2009): Vetiver system for the prevention and treatment of contaminated water and land (special reference to domestic and municipal wastewater treatment in Australia). - Extended Abstract. Ethiopian National Workshop. Addis Abba.

[49] Truong, P. N. V., Foong, Y. K., Guthrie, M., Hung, Y. T. (2010): Phytoremediation of heavy metal contaminated soils and water using Vetiver grass. - Environmental Bioengineering 11: 223-275.

[50] Vargas, C., Pérez-Esteban, J., Escolástico, C., Masaguer, A., Moliner, A. (2016): Phytoremediation of $\mathrm{Cu}$ and $\mathrm{Zn}$ by Vetiver grass in mine soils amended with humic acids. - Environmental Science and Pollution Research 23: 13521-13530.

[51] Vaverková, M. D., Adamcová, D., Radziemska, M., Voběrková, S., Mazur, Z., Zloch, J. (2018): Assessment and evaluation of heavy metals removal from landfill leachate by Pleurotus ostreatus. - Waste and Biomass Valorization 9(3): 503-511.

[52] Wong, J. T. F., Chen, X. W., Mo, W. Y., Man, Y. B., Ng, C. W. W., Wong, M. H. (2015): Restoration of plant and animal communities in a sanitary landfill: a 10-year case study in Hong Kong. - Land Degrad. Dev. 27: 490-499.

[53] Xia, H., Liu, S., Ao, H. (2000): Study on purification and uptake of garbage leachate by Vetiver grass. - Paper presented at the 2nd International Conference on Vetiver, Thailand.

[54] Yaman, M., Akdeniz, I. (2004): Sensitivity enhancement in flame atomic absorption spectrometry for determination of copper in human thyroid tissues. - Analytical Sciences 20(9): 1363-1366.

[55] Ye, Z. H., Baker, A. J. M., Wong, M. H., Willis, A. J. (1997): Zinc, lead and cadmium tolerance, uptake and accumulation by Typha latifolia. - New Phytol. 136(3): 469-480.

[56] Zapata Muñoz, A. F., Zapata Sánchez, C. E. (2013): Un método de gestión ambiental para evaluar rellenos sanitarios. - Gestión Y Ambiente 16(2): 105-120. 